УДК: 657.24:346.12

JEL Classification: M14

\author{
К. В. БЕЗВЕРХИЙ, \\ кандидат економічних наук, \\ докторант кафедри обліку і оподаткувания, \\ ДВНЗ “Кийвський національний економічний університет \\ імені Вадима Гетьмана"
}

\title{
Документальне забезпечення записів у бухгалтерському обліку крізь призму законодавчих новацій
}

Зроблено огляд змін у документальному забезпеченні записів у бухаалтерському обліку. Проведено порівняльний аналіз змін Положення про документальне забезпечення записів у бухгалтерському обліку в розрізі розділів: 1) Загальні положення; 2) Первинні документи; 3) Облікові регістри; 4) Виправлення помилок у первинних документах та облікових регістрах; 5) Організація документообороту: б) Зберігання документів. Методи аналізу та синтезу використано для виокремлення відмінностей у редакиіях Положення про документальне забезпечення записів у бухгалтерському обліку. Результат дослідження мас теоретичну і практичну иінність для діяльності вітчизняних нідприємств.

Ключові слюва: бухгалтерський облік, документ, документування, забезпечення, зanic.

Постановка проблеми та ї̈ зв'язок із практичними завданнями. Бурхливий розвиток економіки і цифрових технологій обумовлює нові завдання у сүері документального забезпечення записів у бухгалтерському обліку, які, на нашу думку, можна вирішити шляхом реформування вітчизняноі системи бухгалтерського обліку. Стрімкі зміни вітчизняного законодавства щодо бухгалтерського обліку сприяють спрощенню його ведення та складання фінансової звітності суб єктами господарювання, що покращуватиме позиції України в глобальному рейтингу ведення бізнесу Doing Business. Таким спрошенням $\epsilon$ прийняття змін до Положення про документальне забезпечення записів у бухгалтерському обліку [1] (надалі - Положення), що затверджені Наказом Міністерства фінансів України № 427 від 11.04.2017 р. [2].

Аналіз останніх досліджень та публікацій. Дослідженням документального забезпечення записів у бухгалтерському обліку займаються багато вченихекономістів (див. [3-8]). Не зменшуючи вагомості наукових результатів провідних учених, зау важимо, що питання, пов язані з документальним забезпеченням записів в бухгалтерському обліку, в їх дослідженнях опрацьовані недостатньо.

Метою дослідження $\epsilon$ аналіз законодавчих новацій документального забезпечення записів в бухгалтерському обліку.

Виклад основного матеріалу дослідження. У наших попередніх дослідженнях було висвітлено питання підтвердження фактів здін̆снення господарсыких операцій за допомогою первинних документів [3].

Порівняльний аналіз змін Положення про документальне забезпечення записів у бухгалтерському обліку наведено в таблищі.

Таблиия

Порівняльнй аналіз змін Положения про документальне забезпечення записів у бухгалтерському обліку (ті пунктп положения, які не зазнали змін, в таблиці

не наводяться)

\begin{tabular}{|c|c|c|}
\hline $\begin{array}{l}\text { No } \\
\text { 3/ח }\end{array}$ & $\begin{array}{c}\text { Положення про документальне } \\
\text { забезпечення записів у } \\
\text { бухгалтерському обліку в редакції } \\
\text { Наказу МФУ № } 987 \text { від } 30.09 .2014 \text { р. }\end{array}$ & $\begin{array}{c}\text { Положения про документальне } \\
\text { забезпечення записів у } \\
\text { бухгалтерському обліку в редакції } \\
\text { Наказу МФУо } 427 \text { від 11.04.2017 р. [2] }\end{array}$ \\
\hline 1 & 2 & 3 \\
\hline
\end{tabular}

(C) К. В. Безверхий, 2017 
Продовження табл.

\begin{tabular}{|c|c|}
\hline 1 & 2 \\
\hline \multicolumn{2}{|r|}{ 1. Загальні пі } \\
\hline 1 & $\begin{array}{l}\text { 1.1. Положения встановлює порядок } \\
\text { створення, прийняття і відображеиия } \\
\text { у бухгалтерському обліку, а також } \\
\text { зберігаиия первинних доку ментів, } \\
\text { облікових регістрів, бухгалтерської } \\
\text { звітності нідприємствами, їх об'єдна- } \\
\text { н н ми, та гос про зраху нко в им и } \\
\text { організаціями (крім банків) незалежно } \\
\text { від форм власності (надалі - нідпри- } \\
\text { ємства), установ та організацій, основна } \\
\text { діяльність яких фінансується за рахунок } \\
\text { коштів бюджету (надалі - установи). }\end{array}$ \\
\hline 2 & $\begin{array}{l}\text { 1.3. Усі первинні документи, облікові } \\
\text { регістри і бухгалтерська звітність пови- } \\
\text { нні складатись українською мовою. } \\
\text { Поряд із українською мовою може } \\
\text { застосовуватись інша мова у порядку, } \\
\text { визначеному Законом України “Про } \\
\text { засади державної мовної політики". }\end{array}$ \\
\hline
\end{tabular}

\section{2. Первннні документи}

3 2.1. Первинні документи - це документи, створені у письмовій або електронній формі, що фіксують та підтверджують господарські операції, включаючи розпорядження та дозволи адміністрації (власника) на їх проведення.

4 2.2. Первинні документи повинні бути складені у момент проведення кожної господарської операції або, якщо це неможливо, безпосередньо після їі завершення. При реалізації товарів за готівку допускається складання первинного документа не рідше одного разу на день на підставі даних касових апаратів, чеків тощо. Для контролю та впорядку вання обробки інформації на основі первинних документів можуть складатися зведені документи (далі - первинні документи).

5 2.4. Первинні документи повинні мати такі обов' язкові реквізити: найменування підприємства, установи, від імені яких складеиий документ, назва документа (форми), дата і місце складання, зміст та обсяг господарської операції, одиниця вимірюваиня господарської операції (у натуральному та/або вартісному виразі), посади і прізвища осіб, відповідальиих за здійснення господарської операції і правильність їі оформлення, особистий чи електронний нідпис або інші дані, що дають змогу ідентифікувати особу, яка брала участь у здійсненні господарської операції.
2.1. Первинні документи - це документи, створені у письмовін̆ або електронній формі, які містять відомості про господарські операції, включаючи розпорядження та дозволи адміністрації (власника) на їх проведення.

2.2. Підставою для бухгалтерського обліку господарських операцій первинні документи. При реалізації товарів за готівку допускається складання первинного документа не рідше одного разу на день на підставі даних касових апаратів, чеків тощо. Для контролю та впорядкування обробки інформації на основі первинних документів можуть складатися зведені документи (далі первинні документи).

\section{4. Первинні документи повинні мати такі обов' язкові реквізити: найменування підприємства. установи, від імені яких складеиий документ, назва документа (форми), дата складання, зміст та обсяг господарської операції, одиииця вимірювання господарської операції (у натуральному та/або вартісному виразі), посади і прізвища осіб, відповідальиих за здійснення господарської операції i правильність ії̈ оформления, особистий nidnuc аб̆о інші дані, що дають змогу ідентифікувати особу, яка брала участь у здійсненні господарської операції.}


Продовження табл.

\begin{tabular}{|c|c|c|}
\hline 1 & 2 & 3 \\
\hline 6 & $\begin{array}{l}\text { 2.6. Фізичпі та юридичпі особи, які } \\
\text { беруть участь у здійсненпі операцій. } \\
\text { пов'язаних з прийомом і видачею } \\
\text { грошових коштів, цінних паперів, } \\
\text { товарно-матеріальних цінностей та } \\
\text { інших об'єктів майна, забезпечуються } \\
\text { підприємством, установою, що виконує } \\
\text { ці операції. копіями первинних доку- } \\
\text { ментів про таку операцію. }\end{array}$ & 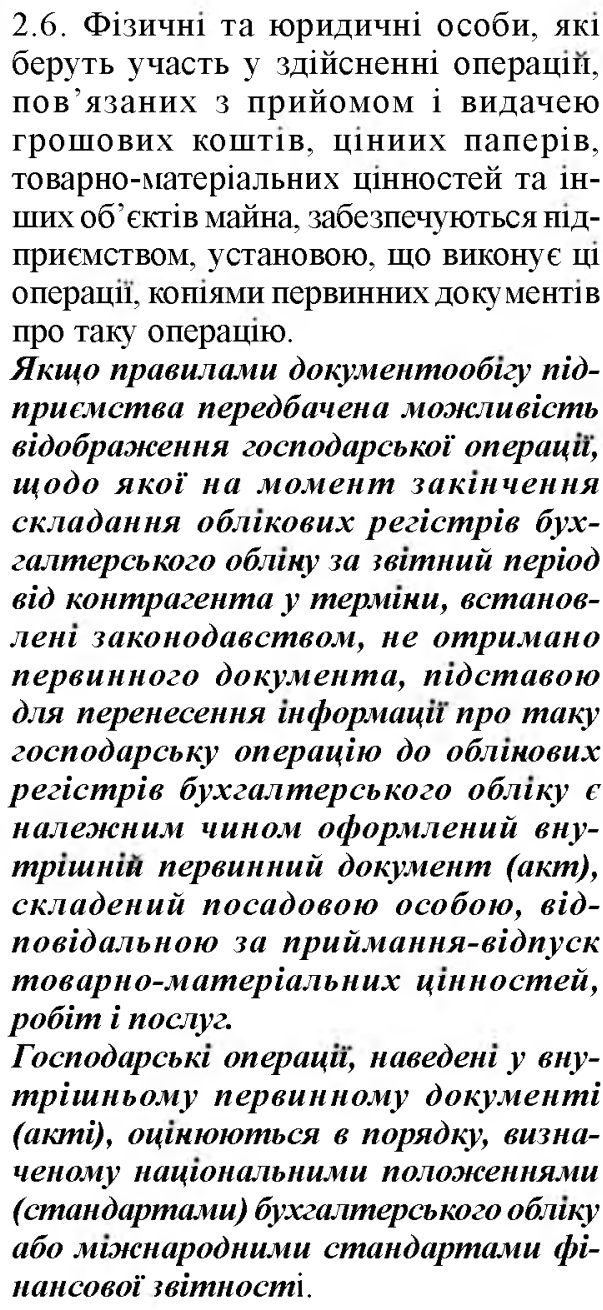 \\
\hline 7 & $\begin{array}{l}\text { 2.9. У випадках, устаиовлеиих законо- } \\
\text { давством, а також відповідиими орга- } \\
\text { нами державної влади України, бланки } \\
\text { первинних документів можуть бути } \\
\text { віднесепі до бланків суворої звітності. } \\
\text { Бланки суворої звітності друкуються за } \\
\text { зразками типових або спеціалізованих } \\
\text { форм, затверджених відповідиим орга- } \\
\text { ном державної влади за погодженням із } \\
\text { спеціальио уповноваженим централь- } \\
\text { иим органом викоиавчої влади у галузі } \\
\text { статистики і Міиістерством фінансів } \\
\text { Україпи, із обов'язковим друкуваииям } \\
\text { на бланках квитаицій, білетів. тало- } \\
\text { пів, абонементів тощо їх номінальної } \\
\text { вартості. Всі бланки суворої звітності } \\
\text { підлягають нумерації, спосіб нанесеи- } \\
\text { ня якої (нумератором, типографським } \\
\text { способом) встаиовлюють відповідні } \\
\text { оргаии державної влади. }\end{array}$ & $\begin{array}{l}\text { 2.9. У випадках, установлеинх законо- } \\
\text { давством, а також відповідними орга- } \\
\text { нами державної влади України, бланки } \\
\text { первинних докумептів можуть бути } \\
\text { віднесепі до бланків суворої звітності. } \\
\text { Бланки суворої звітності друкуються за } \\
\text { зразками типових або спеціалізованих } \\
\text { форм, затверджених відновідним орга- } \\
\text { ном державної влади за погодженням із } \\
\text { центральним органом викоиавчої влади, } \\
\text { ще забезпечує формувания державноі } \\
\text { фінансової політики, із обов'язковим } \\
\text { друкуваииям на бланках квитаицій, } \\
\text { білетів. талонів. абонементів тощо іх } \\
\text { номінальної вартості. Всі бланки суворої } \\
\text { звітності підлягають нумерації. спосіб } \\
\text { нанесення якої (нумератором, типограф- } \\
\text { ським способом) встановлюють відпо- } \\
\text { відні органи державної влади. }\end{array}$ \\
\hline
\end{tabular}




\begin{tabular}{|c|c|c|}
\hline & & Продовження табл. \\
\hline 1 & 2 & 3 \\
\hline 8 & $\begin{array}{l}\text { 2.10. Записи у первинних документах, } \\
\text { облікових регістрах повингі здійснюва- } \\
\text { тися тільки у темному кольорі чорнилом, } \\
\text { пастою кулькових ручок, за допомогою } \\
\text { друкарських машинок,принтерів, за- } \\
\text { собів механізації та іншими засобами, } \\
\text { які б забезпечили збереження цих за- } \\
\text { писів протягом установленого строку } \\
\text { зберігання документів та запобігли вне- } \\
\text { сенню несанкцюнованих і непомітиих } \\
\text { виправлеиь. }\end{array}$ & $\begin{array}{l}\text { 2.10. Записи у первинних документах, } \\
\text { облікових регістрах повингі здійснюва- } \\
\text { тися тільки у темному кольорі чорнилом, } \\
\text { пастою кулькових ручок, за допомогою } \\
\text { електронних засобів обробки інформації } \\
\text { ма іниими засобами, які б забезпечили } \\
\text { збереження цих записів протягом уста- } \\
\text { новленого строку зберігання документів } \\
\text { та запобігли внесенню несанкціонованих } \\
\text { і непомітиих виправлеиь. }\end{array}$ \\
\hline 9 & $\begin{array}{l}\text { 2.13. Керівник підприємства, установи } \\
\text { забезпечує фіксувания фактів здін̆сиеи- } \\
\text { ня всіх господарських операцій, що були } \\
\text { проведені, у первинних документах та } \\
\text { виконання всіма підрозділами, служба- } \\
\text { ми і працівииками правоміриих вимог } \\
\text { головного бухгалтера щодо порядку } \\
\text { оформлення та подання для обліку відо- } \\
\text { мостей і документів. }\end{array}$ & $\begin{array}{l}\text { 2.13. Керівннк підприємства, установи } \\
\text { забезпечує фіксування фактів здійснення } \\
\text { всіх господарських операцій. що були } \\
\text { проведені, у первинних документах та } \\
\text { виконання всіма підрозділами, служба- } \\
\text { ми і працівииками правомірних вимог } \\
\text { головного бухгалтера або особи, на яку } \\
\text { покладено ведення бухгалтерського об- } \\
\text { ліку підприємства, щодо порядку оформ- } \\
\text { лення та подання для обліку відомостей } \\
\text { і документів. }\end{array}$ \\
\hline 10 & $\begin{array}{l}\text { 2.17. Первинпі документи, що пройшли } \\
\text { обробку, повинні мати відмітку. яка } \\
\text { виключає можливість їх повторного ви- } \\
\text { користання: при ручніп̆ обробці - дату } \\
\text { запису в обліковий регістр, а при обробці } \\
\text { наобчислювалыпій установці - відтиск } \\
\text { штампу оператора, відповідальиого за } \\
\text { іхх обробку, або відмітку, придатну для ії } \\
\text { обробки електронними засобами. }\end{array}$ & $\begin{array}{l}\text { 2.17. Первингі документи, що пройшли } \\
\text { обробку, повинні мати відмітку, яка } \\
\text { виключає можливість їх повторного ви- } \\
\text { користання: при ручній обробці - дату } \\
\text { запису в обліковий регістр, а при обробці } \\
\text { елекмронними ма іниими засобами - } \\
\text { відтиск штампу оператора, відповідаль- } \\
\text { ного за їх обробку, або відмітку, придатну } \\
\text { для їі обробки електронними засобами. }\end{array}$ \\
\hline \multicolumn{3}{|c|}{ 3. Облікозі регістри } \\
\hline 11 & $\begin{array}{l}\text { 3.1. Облікові регістри - це носії спеці- } \\
\text { ального формату (паперові, електронпі) } \\
\text { у вигляді відомостей, ордерів, книг, жур- } \\
\text { налів. машинограм тощо, призначені для } \\
\text { хроиологічного, систематичного або ком- } \\
\text { біпованого нагромадження, групування } \\
\text { та узагальнення інформації } 3 \text { первинних } \\
\text { документів, що прийняті до обліку. }\end{array}$ & $\begin{array}{l}\text { 3.1. Облікові регістри - це носії спеціаль- } \\
\text { ного формату (паперові, електронші) у ви- } \\
\text { гляді відомостей, ордерів, книг, журналів } \\
\text { тощо, прнзначені для хронологічного. } \\
\text { систематичного або комбінованого на- } \\
\text { копичеиия, групування та узагальнення } \\
\text { інформації з первинних документів, що } \\
\text { прийняті до обліку. }\end{array}$ \\
\hline 12 & $\begin{array}{l}\text { 3.5. Перенесения інформації з первин- } \\
\text { них доку ментів до облікових регістрів } \\
\text { повинно здійіснюватися в міру їі надхо- } \\
\text { дження до місця обробки (бухгалтерія, } \\
\text { обчислювальна установка), проте не } \\
\text { пізніше терміну, що забезпечує своєчас- } \\
\text { ну виплату заробітиої плати, складання } \\
\text { бухгалтерськоі і статистичної звітності, } \\
\text { декларацій і розрахунків. }\end{array}$ & 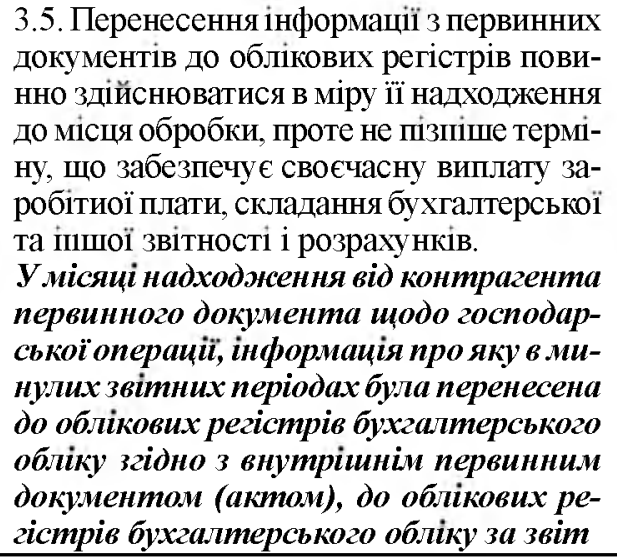 \\
\hline
\end{tabular}


Продовження табл.

\begin{tabular}{|l|l|}
\hline 1 & \multicolumn{1}{|c|}{2} \\
\hline 13 & \\
\hline 13.7 1нформація про господарські опе- \\
рації підприємства, установи за звітиий \\
період (місяць, квартал, рік) 3 облікових \\
регістрів переноситься у згрупованому \\
вигляді до бухгалтерських звітів, по- \\
рядок складання яких встановлюється \\
відповідними нормативио-правовими \\
актами.
\end{tabular}

3

ний період переноситься інформація про таку господарську операцію, при цьому й обсяг зазначасться иляхом коригування на суму різниці між оцінкою такой господарської операції за внутріинім первинним доқументом (актом) та первинним документом, отриманим від контрагента

3.7. 1нформація про господарські операції підприємства, установи за звітиий період (місяць, квартал, рік) з облікових регістрів переноситься у згрупованому вигляді до бухгалтерської та іншої звітності, порядок складання якої встановлюється відповідними нормативиоправовими актами.

\section{4. Виправлення помилок у первиних документах та облікових регістрах}

14 4.1. У тексті та цифрових даних первинних документів. облікових регістрів i звітів підчистки і иеобумовлепі виправлення не допускаються.

15 4.2. Помилки в первинних документах, облікових регістрах і звітах, що створені ручним способом, виправляготься коректуриим способом, тобто неправильний текст або цифри закреслюються і над закресленим надписується правильиий текст або цифри. Закреслення здійснюється одпією рискою так, щоб можна було прочитати виправлеие.

4.1. У тексті та цифрових даних первинних документів, облікових регістрів і звімності підчистки і иеобумовлені виправлення не допускаються.

4.2. Помилки в первинних документах, облікових регістрах і звітності, що створені ручним способом, виправляються способом "червоного сторно", додаткових бухгалтерських проведень або корекмурним способом, відповідно до якого неправильний текст або цифри закреслюються і над закресленим надписується правильиий текст або цифри. Закреслення здійіннюється однією рискою так, щоб можна було прочитати виправлеие.

\section{5. Організація документообороту}

16 5.2. Графік документообороту на підприємстві, в установі повинен забезпечити оптимальну кількість підрозділів і викоиавців, через які проходить кожен первинний документ, визначати мінімальний строк його знаходження в підрозділі, а також сприяти полішшенню облікової роботи, посиленню контрольиих функцій бухгалтерського обліку. підвищеиню рівня його механізації та автоматизації.

17 5.5. Контроль за дотриманням викоиавцями графіка документообороту на підприсмстві, в установі здійснюсться головним бухгалтером. Вимоги головного бухгалтера щодо порядку подання до бухгалтерії або на обчислювальну установку необхідних документів та відомостей $\epsilon$ обов'язковими для усіх підрозділів і служб́ підприємства.
5.2. Графік документообороту на підприємстві, в установі повинен забезпечити оптимальну кількість підрозділів і виконавців, через які проходить кожен первинний документ, визначати мінімальний строк його знаходження в підрозділі, а також сприяти поліпшенню облікової роботи, посиленню контрольних функцій бухгалтерського обліку, підвищеиню рівня його автоматизації.

5.5. Контроль за дотриманням виконавцями графіка документообороту на підприємстві, в установі здійснюється головним бухгалтером або особою, на яку покладено ведення бухгалтерського обліку підприсмства, вимоги яких щодо порядку подання домісця обробки необхідних документів та відомостей $\epsilon$ обов'язковими для усіх підрозділів $\mathrm{i}$ служб підприємства. 
Продовження табл.

\begin{tabular}{|c|c|c|}
\hline 1 & 2 & 3 \\
\hline \multicolumn{3}{|c|}{ 6. 3беері ання ,цокументіз } \\
\hline 18 & $\begin{array}{l}\text { 6.2. Первинпі документи та облікові } \\
\text { регістри, що пройшли обробку, бухгал- } \\
\text { терські звіти і баланси до передачі їх до } \\
\text { архіву підприємства, установи повинні } \\
\text { зберігатися в бухгалтерії у спеціальних } \\
\text { приміщеннях або зачииеиих шафах під } \\
\text { відповідальністю осіб, уповиоважеиих } \\
\text { головним бухгалтером. }\end{array}$ & $\begin{array}{l}\text { 6.2. Первинні документи та облікові } \\
\text { регістри, що пройшли обробку, бухгал- } \\
\text { терська та іниа звітність до передачі їх } \\
\text { до архіву підприємства, установи повинні } \\
\text { зберігатися в бу хгалтерській службі у } \\
\text { спеціальних приміщеинях або зачииеиих } \\
\text { шафах під відповідальністюосіб, уповио- } \\
\text { важених головним бухгалтером. }\end{array}$ \\
\hline 19 & $\begin{array}{l}\text { 6.6. Строк зберігання первинних до- } \\
\text { кументів, облікових регістрів, бух- } \\
\text { галтерської та іншої звітності в архіві } \\
\text { підприємства, установи визначається } \\
\text { згідно з нормативио-правовим актом } 3 \\
\text { питань визначення строків зберігання } \\
\text { документів, затвердженим цеитральиим } \\
\text { органом викоиавчої влади у сфері архів- } \\
\text { иої справи і діловодства. }\end{array}$ & $\begin{array}{l}\text { 6.6. Строк зберігання первинних доку- } \\
\text { ментів, облікових регістрів, бухгалтер- } \\
\text { ської та іншої звітності в архіві підпри- } \\
\text { ємства, установи визначається згідно } 3 \\
\text { нормативио-правовим актом } 3 \text { питань } \\
\text { визначення строків зберігання докумен- } \\
\text { тів, затвердженим центральним органом } \\
\text { викоиавчої влади, що забезиечує фор- } \\
\text { мувания держсавної політики у сфері } \\
\text { архівної справи і діловодства. }\end{array}$ \\
\hline 20 & $\begin{array}{l}\text { 6.7. Зберігання первинних документів } \\
\text { та облікових регістрів, шо пройшли } \\
\text { обробку і були підставою для складання } \\
\text { звітності, а також бухгалтерських звітів } \\
\text { і балансів, оформлення і передачу їх до } \\
\text { архіву забезпечує головний бухгалтер } \\
\text { підприємства, установи. }\end{array}$ & $\begin{array}{l}\text { 6.7. Зберігання первинних документів та } \\
\text { облікових регістрів, що пройшли обробку } \\
\text { і були підставою для складання звіт- } \\
\text { ності, а також бухгалтерської та ікшої } \\
\text { звімності. оформлення і передачу їх до } \\
\text { архіву забезпечує головний бухгалтер } \\
\text { підприємства, установи або особа, на } \\
\text { яку покладено ведення буххалтерського } \\
\text { обліку nidприємства. }\end{array}$ \\
\hline 21 & $\begin{array}{l}\text { 6.8. Видача первинних документів, } \\
\text { облікових регістрів, бухгалтерських } \\
\text { звітів і балансів з бухгалтерії і } 3 \text { архіву } \\
\text { підприємства, установи працівникам } \\
\text { інших структурних підрозділів може } \\
\text { провадитися тільки за рішеиням голов- } \\
\text { ного бухгалтера. }\end{array}$ & $\begin{array}{l}\text { 6.8. Видача первинних документів, облі- } \\
\text { кових регістрів, бухгалтерської та іншої } \\
\text { звітності з буххалтерської служби і } \\
\text { архіву підприємства, установи праців- } \\
\text { никам інших структурних підрозділів } \\
\text { може провадитися тільки за рішенням } \\
\text { головного бухгалтера або особи, на яку } \\
\text { покладено ведення бухгалтерського об- } \\
\text { ліку підприємства. }\end{array}$ \\
\hline 22 & $\begin{array}{l}\text { 6.9. Вилучення первинних документів, } \\
\text { облікових регістрів, фінансової звітності } \\
\text { у підприємств, установ здійснюється } \\
\text { відповідно до законодавства. }\end{array}$ & $\begin{array}{l}\text { 6.9. Вилучення первинних документів, } \\
\text { облікових регістрів, буххалтерської та } \\
\text { іншої звітності у нідприємств, установ } \\
\text { здійснюється відповідно до законодав- } \\
\text { ства. }\end{array}$ \\
\hline 23 & $\begin{array}{l}\text { 6.10. У разі пропажі або зиищеиня пер- } \\
\text { винних документів, облікових регістрів } \\
\text { і звітів керівннк підприємства, установи } \\
\text { письмово повідомляє про це правоохо- } \\
\text { роині органи та наказом призиачає комі- } \\
\text { сію для встановлеиня иереліку відсутніх } \\
\text { документів та розсліду вання причин їх } \\
\text { пропажі або знищення. } \\
\text { Результати роботи комісії оформляються } \\
\text { актом, який затверджуєтья керівииком } \\
\text { підприємства, установи. Копія акта над- } \\
\text { силається органу, в сфері управління яко- } \\
\text { го перебуває підприємство, установа, а }\end{array}$ & $\begin{array}{l}\text { 6.10. У разі пропажі або зиищеиня пер- } \\
\text { винних документів, облікових регістрів } \\
\text { і звітності керівиик нідприємства, } \\
\text { установи письмово повідомляє про це } \\
\text { правоохоронні органи та наказом призна- } \\
\text { чає комісію для встановлеиня переліку } \\
\text { відсутпіх документів та розслідування } \\
\text { причин їх пропажі або зиищеиня. } \\
\text { Результати роботи комісії оформляються } \\
\text { актом, який затверджується керівником } \\
\text { підприємства, установи. Копія акта над- } \\
\text { силається органу, в сфері управління } \\
\text { якого перебуває підприємство, устаиова, }\end{array}$ \\
\hline
\end{tabular}




\begin{tabular}{|c|c|c|}
\hline & & Продовження табл. \\
\hline 1 & 2 & 3 \\
\hline & $\begin{array}{l}\text { також державній податковій інспек- } \\
\text { ції-підприємствами та місцевому фінан- } \\
\text { совому органу -установами, в 10-денний } \\
\text { строк. }\end{array}$ & 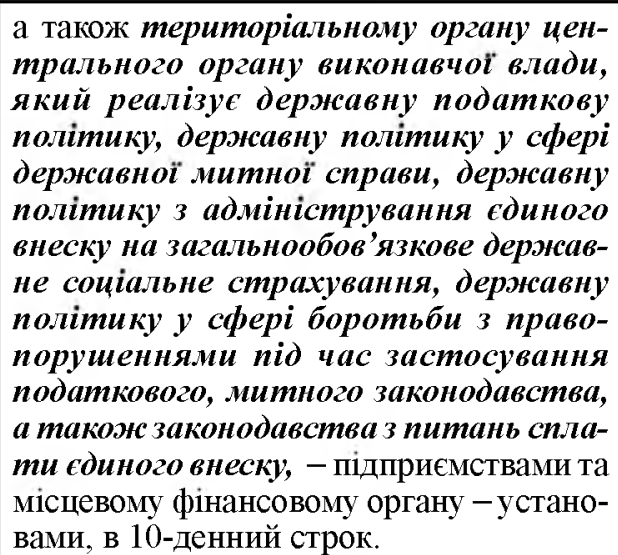 \\
\hline
\end{tabular}

Висновки і перспективи подальших досліджень. Зміни, внесені у Положення [1], привели його норми у відповідність із законодавством та уточнили порядок документального оформлення деяких господарських операцій, а саме:

1) змінили термін “"первинний документ”, що дозволило вважати оплачений (акцептований) рахунок-фактуру (інвойс) підставою для відображення господарсыкої операції в бухгалтерському обліку без обов'язкового складання акта приймання-передачі, а також вилучити реквізит "місце складання";

2) дозволили відображення в бухгалтерському обліку господарських операцій, щодо яких на момент закінчення складання облікових регістрів бухгалтерського обліку за звітний період від контрагента не отримано первинного документа на підставі належно оформленого внутрішнього первинного документа (бухгалтерська довідка) 3 подальшим відображенням у місяці надходження первинного документа від контрагента в облікових регістрах бухгалтерського обліку таких господарських операцій в обсязі, визначеному шляхом коригування на суму різниці між оцінкою господарської операції за внутрішнім первинним документом та первинним документом, отриманим від контрагента.

В подальших наукових дослідженнях пропонується зосередити увагу на електронному документообігу в системі документування. Порушені в статті питання не $\epsilon$ вичерпними й потребують доповнень, змін, уточнень та конкретизації.

\section{Список використаних джерел}

1. Про затвердження Положення про документальне забезпечення записів у бухгалтерському обліку: Наказ Міністерства фінансів України від 24.05.1995 р. № 88 // База даних «Законодавство України» / ВР України. URL: http://zakon2.rada.gov.ua/ laws/show/z0168-95 (дата звернення 10.06.2017).

2. Про затвердження Змін до Положення про документальне забезпечення записів у бухгалтерському обліку: Наказ Міністерства фінансів України від $11.04 .2017 \mathrm{p}$. № 427 // База даних «Законодавство України» / ВP України. URL: http://zakon3. rada.gov.ua/laws/show/z0567-17 (дата звернення 10.06.2017).

3. Безверхий К. Порядок підтвердження фактів здійснення господарсыких операций: обліково-юридичний аспект // Бухгалтерський облік і аудит. 2016. № 4. С. 39-44.

4. Бутинець Т. А. Документування господарських операцій: теорія, методологія, комп'ютеризація: моногр. Житомир: ЖІТ1, 1999. 412 с.

5. Легенчук С. Ф., ВольськаК. О., Вакун О. В. Документування в бухгалтерськомуобліку: процесний підхід: моногр. 1вано-Франківськ: Видавець Кушнір Г. М., 2016. 228 с.

6. Маренич Т. Г. Документальне забезпечення записів у бухгалтерському обліку: аналіз новацій та напрями поліишення // Актуальні проблеми інноваційної економіки. 2017. № 1. С. 76-79.

7. Остап'юк Н. А., Лисюк А. В. Документальне забезпечення витрат на рекламу суб' єкта господарювання // Економіка: реалії часу. 2013. № 4. С. 58-63. 
8. Янчев А. В. Організаційно-методичні положення електронного документування в системі бухгалтерського обліку: дис. ... докт. екон. наук: 08.00.09- “Бухгалтерський облік, аналіз та аудит". Харків, 2015. 465 с.

К. В. БЕЗВЕРХИЙ, кандидат экономических наук, докторант кафедры учета и налогообложсения,

ГВУЗ «Киевский национальный экономический университет имени Вадима Гетьмана»

\section{Документальное обеспечение записей в бухгалтерском учете сквозь призму законодательных новаций}

Сделан обзор изменений документального обеспечения записей в бухгалтерском учете. Проведен сравнительный анализ изменений Положения о документальном обеспечении записей в бухалтерском учете в разрезе разделов: 1) Обиие положения; 2) Первичные документы ; 3) Учетные регистры; 4) Исправление оиибокв первичных документах и учетных регистрах; 5) Ораанизация документооборота; б) Хранение документов. Методы анализа и синтеза использованы для выделения различий в редакииях Положения о документальном обеспечении записей в бухгалтерском учете. Результат исследования имеет теоретическую и практическую иенность для деятельности отечественных предприятий.

Ключевые слова: бухгалтерский учет, документ, документирование, обеспечение, запись.

K. V BEZVERKHIY,

$P h D$ (Economics), Doctoral Student, Department of Accounting and Taxation,

Kyiv National Economic University named after Vadym Hetman

\section{Documentation of Accounting Records in Light of Legislative Innovations}

Legislative reforms in accounting aim to simplify accounting records and compilation offinancial reports by business entities, thus increasing the position of Ukraine in the global ranking of Doing Business. This simplification is implied in the changes in the Regulation on Documentation of Accounting Records, entered into force to the Resolution of the Ukrainian Ministry of Finance. The objective of the study is to analyze the legislative innovations involved. The review of changes in documentation of accounting records is made. A comparative analysis of changes in the Regulation on Documentation of Accounting Records is made by sections: 1) General; 2) Primary documents; 3) Accounting records; 4) Correction of errors in primary documents and accounting records; 5) Organization of document circulation; 6) Storage of documents. Methods of analysis and synthesis are used for separating the differences in the editions of the Regulation on Documentation of Accounting Records. The result of the study has theoretical and practical value for the domestic business enterprise sector.

Keywords: accounting, document, documentation, software, recording.

\section{Посилання на статтю:}

Безверхий К. В. Документальне забезпечення записів у бухгалтерському обліку крізь призму законодавчих новацій // Науковий вісник Націнальної академії статистики, обліку та аудиту: зб. наук. пр. 2017. №3. С. 34-41. 